\title{
Accelerating the implementation of biocatalysis in industry
}

\section{Woodley, John M.}

\section{Published in:}

Applied Microbiology and Biotechnology

Link to article, DOI:

10.1007/s00253-019-09796-x

Publication date:

2019

Document Version

Peer reviewed version

Link back to DTU Orbit

Citation (APA):

Woodley, J. M. (2019). Accelerating the implementation of biocatalysis in industry. Applied Microbiology and Biotechnology, 103(12), 4733-4739. https://doi.org/10.1007/s00253-019-09796-x

\section{General rights}

Copyright and moral rights for the publications made accessible in the public portal are retained by the authors and/or other copyright owners and it is a condition of accessing publications that users recognise and abide by the legal requirements associated with these rights.

- Users may download and print one copy of any publication from the public portal for the purpose of private study or research.

- You may not further distribute the material or use it for any profit-making activity or commercial gain

- You may freely distribute the URL identifying the publication in the public portal

If you believe that this document breaches copyright please contact us providing details, and we will remove access to the work immediately and investigate your claim. 


\title{
Accelerating the Industrial Implementation of Biocatalysis in Industry
}

\section{John M Woodley ${ }^{1}$}

${ }^{1}$ Department of Chemical and Biochemical Engineering, Technical University of Denmark, DK-2800 Kgs. Lyngby, Denmark

E mail: John M Woodley (jw@kt.dtu.dk)

\begin{abstract}
Despite enormous progress in protein engineering, complemented by bioprocess engineering, the revolution awaiting the application of biocatalysis in the fine chemical industry has still not be fully realized. In order to achieve that further research is required on rapid methods for protein engineering using machine learning, mathematical modelling of multi-enzyme cascade processes, process standardization, continuous process technology, identifying improvements required to achieve industrial implementation, downstream processing, enzyme stability modelling and prediction as well as new reactor technology. In this brief mini-review the status of each of these topics will be briefly discussed.
\end{abstract}

Keywords Biocatalysis - Enzymatic conversion

\section{Introduction}

In Nature, enzymes catalyze chemical reactions in a highly efficient manner, making them of great interest to organic chemists as a complementary tool to conventional heterogeneous and homogenous catalysts. Unsurprisingly, therefore for the last 30 years interest in the field of biocatalysis has grown continuously. Examples of the many reaction types that can be catalyzed by commercially available enzymes have been reported and reviewed extensively (e.g. Schmid et al. 2001; Nestl et al 2011; Nestl et al. 2014). In contrast therefore this work will instead focus on the major limitations found with many of these examples, and solutions required to help wider implementation. The reader is directed to more specialist literature as necessary.

In general biocatalytic reactions operate under mild conditions (e.g. neutral $\mathrm{pH}$ and ambient temperature and pressure) at high rates and with exquisite selectivity, making them of great interest in particular for the development of sustainable chemical processes ( $\mathrm{Ni}$ et al. 2014; Sheldon and Brady 2018; Sheldon and Woodley 2018). Over the past few decades the high selectivity of enzymes has been used to great effect in the pharmaceutical industry, in particular to simplify many syntheses of small-molecule active pharmaceutical ingredients (APIs), by cutting the number of reaction steps 
(Pollard and Woodley 2007; Devine et al. 2018). Today, several hundred processes have been implemented in industry and the range of drugs to which biocatalysis has been applied has been extended (Valeur et al. 2017), as well as the application of biocatalysis to drug discovery (Devine et al. 2018). Likewise, in recent years the application of enzymes to lower-priced fine chemistry has also been more extensively investigated, in the hope of converting a petroleum-based industry into one based on sustainable (renewable, cheap and available) feedstocks (Sheldon 2014; Straathof 2014).

However, using enzymes to help synthesize the lowest-priced chemicals (with a few exceptions) is not easy because in Nature enzymes work mostly in water, at low concentrations and with kinetic constants such that reactions can be well controlled (Bar-Even et al. 2011). Likewise natural substrates do not always yield the most useful and valuable products. These challenges also need to be addressed in the pharmaceutical industry, especially as commercial pressures grow.

In order to solve such problems, enzymes need to be modified from their natural function and environment, via protein engineering, using a combination of rational, semi-rational and directed evolution approaches. Altering the size of active site pockets, swapping amino acids around the entrance to the active site, as well as other amino acids (sometimes distal from the active site) can all be used to tune enzyme activity to non-natural substrates and give improved stability under nonnatural conditions (Turner 2009; Strohmeier et al. 2011; Bornscheuer et al. 2012; Liszka et al, 2012; Reetz 2016; Arnold 2018). Spectacular progress has been made in this field, but while such an approach is a necessary prerequisite for effective implementation of a new biocatalytic reaction, it is frequently not sufficient. In many cases bioprocess engineering is an essential complement to biocatalyst modification. Here too significant progress has been made in recent years, briefly summarized in Figure 1, where some of the major contributions in biocatalyst format design, reaction and reactor design, as well as downstream process design, are listed.

\section{Insert Figure 1 here}

Nevertheless, many of these design methods still require further research and innovation. Indeed, the revolution that awaits the fine chemical industry through the application of biocatalysis has still not yet emerged. In order to achieve that, several bottlenecks need to be addressed and in this minireview, progress in each of these areas will be highlighted.

For reasons of clarity the challenges are divided between higher-priced products (such as pharmaceuticals) and the lower-priced products (although not bulk chemicals, which is beyond the scope here). The two groups have different implementation drivers and therefore different requirements to ensure effective implementation in an industrial setting. A brief summary is given in Table 1. 
Insert Table 1 here.

\section{Higher-priced products}

The synthesis and production of the higher-priced products, such as pharmaceuticals, represents the industrial sector in which biocatalysis has had the greatest impact to date. Here the processes take advantage of the superb selectivity of enzymes, as well as their ability to work under mild conditions, meaning that many processes can eliminate molecular protection and de-protection steps. In this way the number of reaction steps can be cut and thereby processes simplified. Indeed the elimination of process steps in the synthesis of APIs is one of the major drivers for implementation of enzymatic reaction steps. Several hundred processes have been implemented to date, with a trend shifting increasingly from resolution reactions (with a maximum yield of $50 \%$, although very effective for producing optically pure products) to asymmetric synthesis (with a maximum yield of 100\%) (Lalonde 2016). For the synthesis of chiral alcohols (de Wildeman et al. 2007; Moore et al. 2007) and chiral amines (Höhne and Bornscheuer 2009; Kohls et al. 2014; Ghislieri and Turner, 2014) the application of enzymes has even become the preferred method of choice. Examples such as the very well-known enzymatic syntheses of Atorvastatin (Ma et al. 2010) and Sitagliptin (Savile et al. 2010) set excellent benchmarks to demonstrate what is achievable. Nevertheless, some challenges remain, as indicated in the following sections.

- Speeding-up enzyme development. The complexity of the molecules in the pharmaceutical industry means that a significant part of the early development work needs to be focused on enzyme improvement via protein engineering. Without such work, a given (wild-type) enzyme will have little (or no) activity against large, non-natural substrates, meaning large amounts of protein are required. In order to speed-up the enzyme improvement process it is necessary to use structural knowledge to guide protein engineering (Wijma et al. 2013). The need for ever greater speed is clear, and has always been a major driver in pharmaceutical process development, but a significant challenge now lies ahead for biocatalysis (Truppo 2017). Nevertheless, it seems highly likely that artificial intelligence and machine learning methods will be used to revolutionize this process (Yang et al. 2018). Additionally, new equipment capable of high throughput workflows will also be required such as the use of microfluidic droplet sorting (Kintses et al. 2010), also coupled to advanced and generic analytical methods such as mass spectrometry (Diefenbach et al. 2018).

- Modelling cascades. A second key challenge concerns the need to address cascade processes in a more systematic manner. Cascade processes, using multiple enzymes in sequential, parallel or orthogonal networks are an excellent way to capitalize upon a special feature of biocatalysis: that many enzymes function under mostly similar conditions of $\mathrm{pH}$ and temperature. In recent years many cascades have been proposed and experimentally tested, as it becomes clear this is the way to truly build novel synthetic schemes to existing or novel products (Simon et al. 2013; Tauber et 
al. 2013; Wang and Reetz 2015; Sigrist et al. 2015; France et al. 2017; Schrittwieser et al. 2017; Aalbers and Fraaije 2017; de M Silva et al. 2018). However, despite the excellent experimental proofs-of-concept, the challenge remains how to operate such processes in an optimal way, to minimize enzyme use, and maximize productivity. Here it is clear that the effect of an entire cascade on kinetics and thermodynamics needs to be identified (Palacio et al. 2016). The use of mathematical modelling tools is a powerful technique to assist here. A number of groups are starting to address this problem (Findrik et al. 2014), although the selection of the objective function itself remains difficult.

- Process standardization. A characteristic of pharmaceutical process development is the high attrition rate from initial molecular concept to launch. Indeed from several thousand molecules initially of interest, just one will emerge as the final target. Therefore, at a very early stage the synthetic methodology is largely irrelevant, whilst later a more robust strategy must be applied in order to synthesize grams, and later kilograms of material for clinical trials. However, even at the clinical trial stage the number of potential targets makes it hard to justify significant synthetic development effort. One possible approach is therefore to standardize processes, while accepting that not all molecules will fit the standard technology package. If $80 \%$ of molecules can be processed then it is probably sufficient and will represent huge savings in scale-up time and subsequent development efforts. This also matches with the need to use multi-purpose plant, flexible enough to handle different substrates and enzymes.

- Continuous process technology. Finally, in all areas of the pharmaceutical industry there has been a major drive in recent years towards continuous processes. The motivations have been of different types, but include the need to reduce the footprint of processes and improve on safety concerns. Thereby it has been inevitable that interest has grown in the possibilities of using biocatalysis in continuous processes (Tamborini et al. 2017; Britton et al. 2018). Unlike other areas of biotechnology, where growing cells are used for the synthesis and molecular biology is used to alter genes at the plasmid level, in biocatalysis since the synthetic machinery is used as a catalyst (and therefore independent of cell growth (Klamt et al. 2018)), continuous operation looks very attractive. Nevertheless, the prerequisite is sufficient enzyme stability (which will be discussed further in the following section). In biocatalysis because temperature and pressure profiles are rarely used in processes, the benefits of plug-flow are potentially not as obvious as for other catalytic processes, although maintenance of a defined residence time still looks attractive and operation in plug flow is also favored due to enzyme kinetics (which follow a mixed order rate law). In general the supply of multiple phases (liquid-liquid or gas-liquid) in reaction tubes present problems since channeling leading to imperfect plug-flow frequently occurs, resulting in poor interphase mass transfer. Particular challenges arise with the supply of oxygen (which has an 
especially low water-solubility) where a number of solutions have recently been proposed (Bolivar et al. 2018).

\section{Lower-priced products}

For lower priced products, the drivers for industrial implementation are a little different, since the economic potential of a given biocatalytic reaction becomes the major emphasis, rather than development speed. This also means that it is necessary to understand the economic limitations, as well as what it is possible to change in the process in order to make the reaction commercially viable.

- Identifying what needs to be improved in a potential process. While the potential improvements required (such as reaction rate or enzyme stability) of a given enzyme in a biocatalytic process can be identified relatively easily, it is another thing to establish the extent of improvements required. Preconceived notions about the importance of enzyme cost, frequently override the need for improved product concentration, for example. Another misconception is that increasing spacetime yield (or productivity) is a limitation. In reality by adding a higher concentration of enzyme, the rate can always be increased, up to a mass transfer limit. Two tools are very useful here to help analyze the reaction. The first tool is to use a set of process performance metrics (economic surrogates) in order to measure the process performance under given conditions. These metrics (including reaction yield ( $\left.g_{\text {product }} / g_{\text {substrate }}\right)$, productivity $\left(g_{\text {product }} / L_{\text {reactor }} \cdot h_{\text {reaction time }}\right)$, product concentration ( $g_{\text {product }} / L_{\text {reactor }}$ ) and biocatalyst yield ( $\left.g_{\text {product }} / g_{\text {biocatalyst }}\right)$ ) can be used to quickly assess the performance of a laboratory process, and evaluate what improvements are required for industrial implementation. The second tool is to benchmark these metrics against industry standards. This helps establish to what extent improvements are required. Providing a target in this way can enable a research and development plan to be designed to reach suitable metrics for commercialization, prior to scale-up. Suitable software is still lacking to do this effectively and indeed there could be significant value in building a database of economically feasible cases, to assist benchmarking. The use of the process performance metrics also overcomes the often unknown relationship between reaction performance and process economy. Especially when new products are produced using biocatalytic methods, unknown product market and value make this particularly difficult. Likewise sustainability assessments will increasingly be required in the future, as more emphasis is placed on other implementation measures, aside from economics. This becomes even more important for bigger volume (low-priced) products. Whilst some progress has been made here using life cycle analysis (LCA)(Nielsen et al 2007; Kim et al. 2009; Ni et al. 2014), a simplified (and standardized) approach agreed by all would assist enormously. In many cases the feedstock, use of water and use of enzyme dominate such analyses, again emphasizing the importance of the process performance metrics to measure reaction yield, productivity, product concentration and biocatalyst yield, as a first indicator of sustainability. 
- Downstream processing. A second major challenge is in the area of downstream processing. It is widely recognized that the use of water as a reaction medium, means that recovery is particularly problematic. First many of the most interesting products are poorly water-soluble so they are present at low concentrations in the vicinity of the enzyme. Additionally the water in the reactor eventually needs to be removed in order to concentrate the product. Without this concentration step, the downstream process becomes too large and expensive to commercialize. The high boiling point of water means that concentration by evaporation is expensive, especially since the reactions usually take place at ambient conditions. Much more research is required into downstream recovery to establish generic recovery approaches, especially since a further issue is that in many cases product molecules are very similar to substrate molecules. For example, with a single functional group change in a reaction it is hard to find properties to differentiate sufficiently product form substrate to enable an efficient separation. A particular topic of importance includes the avoidance of emulsification from two-liquid phase systems. Indeed the formation by soluble enzyme acting as a surfactant at the liquid-liquid interface is common at high biocatalyst loadings, and potentially leads to significant losses in the subsequent product recovery. Likewise systematic methods for solvent selection for extraction are required as well as enzyme recovery for subsequent recycle. Alternative reaction media should also be further investigated. The removal of the product from the reaction site, as it is formed, termed in situ product recovery (ISPR), comes with a number of benefits (van Hecke et al. 2014). ISPR involves the simultaneous removal of product during the reaction, such that the reactor can operate in a semi-continuous mode. Hence a lower product concentration can be used, resulting in a higher productivity (overcoming inhibition effects). More complex options, incorporating substrate supply can also be considered (Leis et al. 2017). Some excellent examples illustrate many of the requirements for ISPR, but still systematic methods to guide implementation are missing.

- Enzyme immobilization. The use of immobilized enzymes has been a topic of research for much of the last 30 years in biocatalysis, and yet with a few notable exceptions it has proven much harder to scale-up such technology. That is somewhat ironic, given that this was a technique developed with scale-up in mind. The original motivation was to ensure a clean downstream process, later to improve separation and later still to assist enzyme stabilization. Today the cost of enzymes is much reduced thanks to recombinant DNA technology, improved enzyme expression, secretion and improved recovery operations. Nevertheless for low-priced products the need remains for higher levels of stability and enzyme recycle, to reduce the cost contribution of the enzyme. In particular, immobilization has an important role in flow biocatalysis (Bolivar et al. 2017; Thompson et al. 2018; Böhmer et al. 2018) so that packed beds in plug flow mode can be used. Likewise it is important to understand how to operate such systems in an optimal way, including optimization of the amount of protein that can be loaded (Fernandez-Lopez et al. 2017), whilst avoiding 
diffusional limitations. Many challenges remain here, especially in choosing generic immobilization methods, which are cheap and scalable, as well as evaluating reactor configurations at larger scale (where pressure drop can be a limitation in packed beds).

- Enzyme stability modelling and prediction. Kinetics and thermodynamics can be measured relatively easily in the laboratory and with sufficient data parameters can be fitted to mechanistically-based equations. Such models are sufficiently well understood that they can be used to predict process performance under different conditions, and therefore prove invaluable for design of processes, based on laboratory data. However, achieving this is much harder for enzyme stability measurements. Although progress has been made in the field, too few are actively engaged in developing new technology to automate well-designed enzyme stability measurements and thereby distinguish effectively between thermodynamic, kinetic and operational stability (Polizzi et al. 2007; Bommarius and Paye 2013). Effective mathematical models which describe enzyme stability under different conditions are of great importance to predict the biocatalyst yield (total amount of product produced for a given loading of biocatalyst) and thereby the cost contribution of the biocatalyst to the final operating costs. This is one of the very important roles of mathematical modelling, especially in a field like bioprocess engineering.

- Enzyme reactor technology. For lower-priced products, process plant and equipment will be mostly dedicated (to the production of a single product) and this can also provide an opportunity for novel reactor design. One of the most important reactions in organic chemistry is oxidation. Biologically mediated oxidation is a growing and important area of technology for the future (Turner 2011; Tan et al. 2018; Dong et al. 2018; Liu et al 2018), due to the possibility of using a harmless oxidant, renewable catalyst and with reduced waste. Nevertheless since oxygen has a very low water-solubility (the likely medium for enzyme reactions), it presents several challenges for effective operation. This represents an excellent example where reactor technology can help with implementation (Bolivar et al. 2018).

\section{Summary}

The award of one half the 2018 Nobel Prize for Chemistry to Frances Arnold, for developments in enzyme engineering, is a fitting landmark in the development of the biocatalysis research field. We have now learnt that improvements need to be made to the enzyme, such that it can fit the requirements of a given process, rather than the other way round (see Figure 2).

\section{Insert Figure 2 here}

Nevertheless this is just the first step, since next we need to use structural knowledge (and potentially machine learning) to speed-up this process. Likewise the design improvements required of biocatalysts should be informed by process economic requirements. 
Enormous progress has been made in the last decades, and with the help of further research, as well as technology developments (See Table 2) the route to implementation will become clear.

Insert Table 2 here

Finally the major challenge ahead will lie in convincing others of the power of this technology. Hence sustainability analyses, alongside economic analyses will be required, together with further published benchmarking and demonstration examples.

While the targets suggested here are all important for the future, the increasing shift towards sustainability, alongside economy will likely see an ever increasing part of the chemical industry impacted by biocatalysis. This will raise one final issue, the need to integrate biocatalysis with chemocatalysis (Rudroff et al. 2018), as well as the need for retrosynthetic tools, building on already recently proposed methods (Turner and O’Reilly 2013; Green and Turner 2016; Hönig et al. 2017; de Souza et al. 2017).

\section{Compliance with Ethical Standards}

The author declares that he has no conflict of interest.

This article does not contain any studies with human participants or animals performed by the author.

\section{References}

Aalbers FS, Fraaije MW (2017) Coupled reactions by coupled enzymes: Alcohol to lactone cascade with alcohol dehydrogenase-cyclohexanone monoxygenase fusions. Appl Microbiol Biotechnol 101:7557-7658

Arnold FH (2018) Directed evolution: Bringing new chemistry to life. Angew Chem Int Ed 57:41434148

Bar-Even A, Noor E, Savir Y, Liebermeister W, Davidi D, Tawfik DS, Milo R (2011) The moderately efficient enzyme: Evolutionary and physicochemical trends shaping enzyme parameters. Biochemistry 50:4402-4410

Böhmer W, Knaus T, Volkov A, Slot TK, Shiju NR, Casimjee KE, Mutti FG (2018) Highly efficient production of chiral amines in batch and continuous flow by immobilized $\omega$.transaminases on controlled porosity lass metal-ion affinity carrier. J Biotechnol 10.1016/j.jbiotec.2018.12.001 
Bolivar JM, Luley-Goedl C, Leitner E, Sawangwan T, Nidetzky B (2017) Production of glucosyl glycerol by immobilized sucrose phosphorylase: Options for enzyme fixation on a solid support and application in microscle flow format. J Biotechnol 257:131-138

Bolivar JM, Mannsberger A, Thomsen MS, Tekautz G, Nidetzky B (2018) Process intensification for $\mathrm{O}_{2^{-}}$ dependent enzymatic transformations in continuous single-phase pressurized flow. Biotech Bioeng 10.1002/bit.26886

Bommarius AS, Paye MF (2013) Stabilizing biocatalysts. Chem Soc Rev 42:6534-6565

Bornscheuer UT, Huisman GW, Kazlauskas RJ, Lutz S, Moore JC, Robins K (2012) Engineering the third wave of biocatalysis. Nature 485:185-194

Britton J, Majumdar S, Weiss GA (2018) Continuous flow biocatalysis. Chem Soc Rev 47:5891-5918

Burton SG, Cowan DA, Woodley JM (2002) The search for the ideal biocatalyst. Nature Biotech 20:3745

Cantone S, Hanefeld U, Basso A (2007) Biocatalysis in non-conventional media - ionic liquids, supercritical fluids and the gas phase. Green Chem 9:954-971

Devine PN, Howard RM, Kumar R, Thompson MP, Truppo MD, Turner NJ (2018) Extending the application of biocatalysis to meet the challenges of drug development. Nature Rev 10.1038/s41570-018-0055-1

Diefenbach XW, Farasat I, Guetschow ED, Welch CJ, Kennedy RT, Sun S, Moore JC (2018) Enabling biocatalysis by high-throughput protein engineering using droplet microfluidics coupled to mass spectrometry, ACS Omega 3:1498-1508

Dong J, Fernandez-Fueyo E, Hollmann F, Paul C, Pasic M, Schmidt S, Wang Y, Younes S, Zhang W (2018) Biocatalytic oxidation reactions - a chemist's perspective. Angew Chem Int Ed 57:9238-9261

Fernandez-Lopez L, Pedero SG, Lopez-Carrobles N, Gorines BC, Virgen-Ortiz JJ, Fernenadez-Lafuente R (2017) Effect of protein load on stability of immobilized enzymes 98:18-25

France SP, Hepworth LJ, Turner NJ, Flitsch SL (2017) Constructing biocatalytic cascades: In vitro and in vivo approaches to de novo multi-enzyme pathways. ACS Catal 7:710-724

Ghislieri D, Turner NJ (2014) Biocatalytic approaches to the synthesis of enantiomerically pure chiral amines. Top Catal 57:284-300 
Green AP, Turner NJ (2016) Biocatalytic retrosynthesis: Redsigning synthetic routes to high-value chemicals. Persp Science 9:42-48

van Hecke W, Kaur G, de Wever H (2014) Advances in in-situ product recovery (ISPR) in whole cell biotechnology during the last decade. Biotech Adv 32:1245-1255

Höhne M, Bornscheuer UT (2009) Biocatalytic routes to optically active amines. ChemCatChem 1:4251

Hönig M, Sondermann P, Turner NJ, Carreira EM (2017) Enantioselective chemo- and biocatalysis: Partners in retrosynthesis. Angew Chem Int Ed 56:8942-8973

Hollmann F, Arends IWCE, Buehler K (2010) Biocatalytic redox reactions for organic synthesis: Nonconventional regeneration methods. ChemCatChem 2:762-782

Kim S, Jimenez-Gonzalez C, Dale BE (2009) Enzymes for pharmaceutical applications - a cradle-to-gate life cycle assessment. Int J Life Cycle Assess 14:392-400

Kintses B, van Vliet LD, Devenish SRA, Hollfelder F (2010) Microfluidic droplets: New integrated workslows for biological experiments. Curr Opin Chem Biol 14:548-555

Klamt S, Mahadevan R, Hädicke O (2018) When do two-stage processes outperform one-stage processes? Biotechnol J 13:1700539

Kohls H, Steffen-Munsberg F, Höhne M (2014) Recent achievements in developing the biocatalytic toolbox for chiral amine synthesis. Curr Opin Chem Biol 19:180-192

Lalonde J (2016) Highly engineered biocatalysts for efficient small molecule pharmaceutical synthesis. Curr Opin Biotechnol 42:152-158

Leis D, Lauß B, Macher-Ambrosch R, Pfennig A, Nidetzky B, Kratzer R (2017) Integration of whole-cell reaction and product isolation: Highly hydrophobic solvents promote in situ substrate supply and simplify extractive product isolation. J Biotechnol 257:110-117

Liszka MJ, Clark ME, Schneider E, Clark DS (2012) Nature versus nurture: Developing enzymes that function under extreme conditions. Annu Rev Chem Biomol Eng 3:77-102

Liu J, Wu S, Li Z (2018) Recent advances in enzymatic oxidation of alcohols. Curr Opin Chem Biol 43:77-86

Ma SK, Gruber J, Davis C, Newman L, Gray D, Wang A, Grate J, Huisman GW, Sheldon RA (2010) A green-by-design biocatalytic process for atorvastatin intermediate. Green Chem 12:81-86 
Moore JC, Pollard DJ, Kosjek B, Devine PN (2007) Advances in the enzymatic reduction of ketones. Acc Chem Res 40:1412-1419

Nestl BM, Nebel BA, Hauer B (2011) Recent progress in industrial biocatalysis. Curr Opin Chem Biol 15:187-193

Nestl BM, Hammer SC, Nebel BA, Hauer B (2014) New generation of biocatalysts for organic synthesis. Angew Chem Int Ed 53:3070-3095

Ni Y, Holtmann D, Hollmann F (2014) How green is biocatalysis? To calculate is to know. ChemCatChem 6:930-943

Nielsen PH, Oxenbøll KM, Wenzel H (2007) Cradle-to-gate environmental assessment of enzyme products produced industrially in Denmark by Novozymes A/S. Int J LCA 12:432-438

Palacio CM, Crismaru CG, Bartsch S, Navickas V, Ditrich K, Breuer M, Abu R, Woodley JM, Baldenius K, Wu B, Janssen DB (2016) Enzymatic network for production of ether amines from alcohols. Biotech Bioeng 113:1853-1861

Paul CE, Hollmann F (2016) A survey of synthetic nicotinamide cofactors in enzymatic processes. Appl Microbiol Biotechnol 100:4773-4778

Polizzi KM, Bommarius AS, Broering JM, Chaperro-Riggers JF (2007) Stability of biocatalysts. Curr Opin Chem Biol 11:220-225

Pollard DJ, Woodley JM (2007) Biocatalysis for pharmaceutical intermediates: The future is now. Trends Biotechnol 25:66-73

Reetz MT (2016) What are the limitations of enzymes in synthetic organic chemistry? Chem Rec $16: 2449-2459$

Rudroff F, Mihovilovic MD, Gröger H, Snajdrova R, Iding H, Bornscheuer UT (2018) Opportunities and challenges for combining chemo- and biocatalysis. Nature Catal 1:12-22

Savile CK, Janey JM, Mundorff EC, Moore JC, Tam S, Jarvis WR, Colbeck JC, Krebber A, Fleitz FF, Brands J, Devine PN, Huisman GW, Hughes GJ (2010) Biocatalytic asymmetric synthesis of chiral amines from ketones applied to Sitagliptin manufacture. Science 329:305-309

Schmid A, Dordick JS, Hauer B, Kiener A, Wubbolts M, Witholt B (2001) Industrial biocatalysis today and tomorrow. Nature 409:258-268 
Schrittwieser JH, Velikogne S, Hall M, Kroutil W (2017) Artificial biocatalytic linear cascades for preparation of organic molecules. Chem Rev 118:270-348

Sheldon RA (2014) Green and sustainable manufacture of chemicals from biomass: state of the art. Green Chem 16:950-963

Sheldon RA, Brady D (2018) The limits to biocatalysis: Pushing the envelope. ChemComm 54:60886104

Sheldon RA, Woodley JM (2018) The role of biocatalysis in sustainable chemistry. Chem Rev 118:801834

Sigrist R, Zucoloto da Costa B, Marsaioli AJ, Gonzaga de Oliveira L (2015) Nature-inspired enzymatic cascades to build valuable compounds. Biotechnol Adv 33:394-411

de M Silva MV, Costa ICR, de Souza ROMA, Bornscheuer UT (2018) Biocatalytic cascade reaction for the asymmetric synthesis of L- and D-homoalanine. ChemCatChem 10.1002/cctc.201801413

Simon RC, Richter N, Busto E, Kroutil W (2013) Recent developments of cascade reactions involving $\omega$ transaminases. ACS Catal 4:129-143

de Souza ROMA, Miranda LSM, Bornscheuer UT (2017) A retrosynthetic approach for biocatalysis in organic synthesis. Chem Eur J 23:12040-12063

Straathof AJJ (2014) Transformation of biomass into commodity chemicals using enzymes or cells. Chem Rev 114:1871-1908

Strohmeier GA, Pichler H, May O, Gruber-Khadjawi M (2011) Application of designed enzymes in organic synthesis. Chem Rev 111:4141-4164

Tamborini L, Fernandes P, Paradisi F, Molinari F (2018) Flow bioreactors as complementary tools for biocatalytic process intensification. Trends Biotechnol 36:73-88

Tan Q, Qiu J, Luo X, Zhang Y, Liu Y, Chen Y, Yuan J, Liao W (2018) Progress in one-pot bioconversion of cephalosporin C to 7-aminocephalosporanic acid. Curr Pharma Biotechnol 19:30-42

Tauber K, Fuchs M, Sattler JH, Pitzer J, Pressnitz D, Koszlewski D, Faber K, Pfeffer J, Haas T, Kroutil W (2013) Artificial multi-enzyme networks for the asymmetric amination of sec-acohols. Chem Eur J 19:4030-4035

Thompson M, Penafiel I, Cosgrove SC, Turner NJ (2018) Biocatalysis using immobilized enzymes in continuous flow for the synthesis of fine chemicals. Org Proc Res Dev 10.1021/acs.oprd.8b00305 
Truppo MD (2012) Cofactor recycling for enzyme catalyzed processes. Comp Chirality 7:46-70

Truppo MD (2017) Biocatalysis in the pharmaceutical industry: The need for speed. ACS Med Chem Lett 8:476-480.

Turner NJ (2009) Directed evolution drives the next generation of biocatalysts. Nature Chem Biol $5: 567-573$

Turner NJ (2011) Enantioselective oxidation of C-O and C-N bonds using oxidases. Chem Rev 111:4073-4087

Turner NJ, O’Reilly E (2013) Biocatalytic retrosynthesis. Nature Chem Biol 9:285-288

Valeur E, Gueret SM, Adihou H, Gopalakrishnan R, Lemurell M, Waldmann H, Grossmann TN, Plowright AT (2017) New modalities for challenging tragets in drug discovery. Angew Chem Int Ed 56:10294-10323

Wang J-B, Reetz MT (2015) Chiral cascades. Nature Chem 7:948-949

Wijma HJ, Floor RJ, Janssen DB (2013) Structure- and sequence-analysis inspired engineering of proteins for enhanced thermostability. Curr Opin Struct Biol 23:588-594

de Wildeman SMA, Sonke T, Schoemaker HE, May O (2007) Biocatalytic reductions: From lab curiosity to 'First Choice'. Acc Chem Res 40:1260-1266

Woodley JM (2017) Integrating protein engineering with process design for biocatalysis. Phil Trans $R$ Soc (Lond) A 376:20170062

Yang KE, Wu Z, Arnold FH (2018) Machine learning in protein engineering. Q-bio.BM arXiv:1811.10775v1 


\section{Figure captions}

Fig. 1 Bioprocess engineering developments in the field of biocatalysis. Example references: 1. Bolivar et al. 2017, Böhmer et al. 2018, Thompson et al. 2018; 2. Hollmann et al. 2010, Truppo 2012, Paul and Hollmann 2016; 3. France et al. 2017; de M Silva et al 2018; 4. Findrik et al 2014; 5. Britton et al 2018; Tamborini et al 2018; 6. Cantone et al. 2007; 7. van Hecke et al. 2014.

Fig. 2 The new design paradigm by designing the biocatalyst to match the process, in order to ensure process performance metrics can be reached. Figure based on concepts presented in Burton et al. 2002 and Woodley 2017. 
Table 1 Biocatalytic synthesis product classes and their characteristics.

\begin{tabular}{|l|l|l|}
\hline Characteristic & Low-priced products & High-priced products \\
\hline Example price range & 3 to 20 USD/kg & $\begin{array}{l}100 \text { to greater than } 1000 \\
\text { USD/kg }\end{array}$ \\
\hline Implementation driver & Economy & Speed of development \\
\hline Plant & Dedicated & Multi-purpose \\
\hline $\begin{array}{l}\text { Biocatalysis implementation } \\
\text { driver }\end{array}$ & $\begin{array}{l}\text { Sustainable feedstocks and } \\
\text { conversions }\end{array}$ & $\begin{array}{l}\text { Reduced number of process } \\
\text { steps and sustainability of } \\
\text { conversions }\end{array}$ \\
\hline
\end{tabular}


Table 2 Examples of potential future research and technology requirements to accelerate the implementation of biocatalysis in industry.

\begin{tabular}{|c|c|c|}
\hline Driver & $\begin{array}{l}\text { Research } \\
\text { requirements }\end{array}$ & Technology requirements \\
\hline $\begin{array}{l}\text { - Speeding-up enzyme } \\
\text { development by better } \\
\text { protein engineering }\end{array}$ & $\begin{array}{l}\text { - Increased use of structural } \\
\text { information guided by Al and } \\
\text { machine learning } \\
\text { - Integration with process } \\
\text { requirements }\end{array}$ & $\begin{array}{l}\text { - Equipment for high } \\
\text { throughput workflows }\end{array}$ \\
\hline $\begin{array}{l}\text { - Systematic optimization of } \\
\text { enzymatic cascades }\end{array}$ & $\begin{array}{l}\text { - Mathematical models of } \\
\text { thermodynamics and kinetics } \\
\text { of cascades }\end{array}$ & \\
\hline - Process standardization & & $\begin{array}{l}\text { - Standardized process } \\
\text { modules }\end{array}$ \\
\hline $\begin{array}{l}\text { - Continuous process } \\
\text { technology }\end{array}$ & $\begin{array}{l}\text { - Optimization and scale-up } \\
\text { methods }\end{array}$ & - Multiphasic operation \\
\hline $\begin{array}{l}\text { - Identifying what needs to be } \\
\text { improved in a potential } \\
\text { process }\end{array}$ & $\begin{array}{l}\text { - Software to facilitate } \\
\text { application of process } \\
\text { performance metrics } \\
\text { - Standardized methods for } \\
\text { sustainability analysis and } \\
\text { assessment }\end{array}$ & \\
\hline - Downstream processing & $\begin{array}{l}\text { - } \text { Extraction and recovery } \\
\text { schemes } \\
\text { - } \quad \text { Enzyme recovery and recycle } \\
\text { - } \quad \text { ISPR }\end{array}$ & \\
\hline - Enzyme immobilization & - Immobilization protocols & $\begin{array}{l}\text { - } \\
\text { supw immobilization } \\
\text { supports }\end{array}$ \\
\hline $\begin{array}{l}\text { Enzyme stability modelling } \\
\text { and prediction }\end{array}$ & - Stability modelling & $\begin{array}{ll}\text { - } & \text { Automated stability } \\
\text { measurement equipment }\end{array}$ \\
\hline - Enzyme reactor technology & & - Oxygen supply equipment \\
\hline
\end{tabular}




\section{Figure 1}

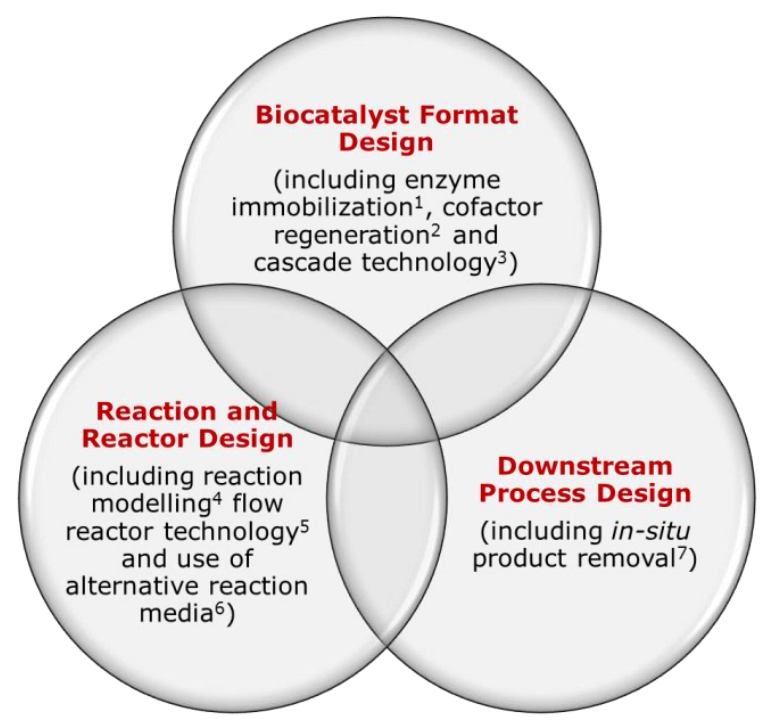


Figure 2

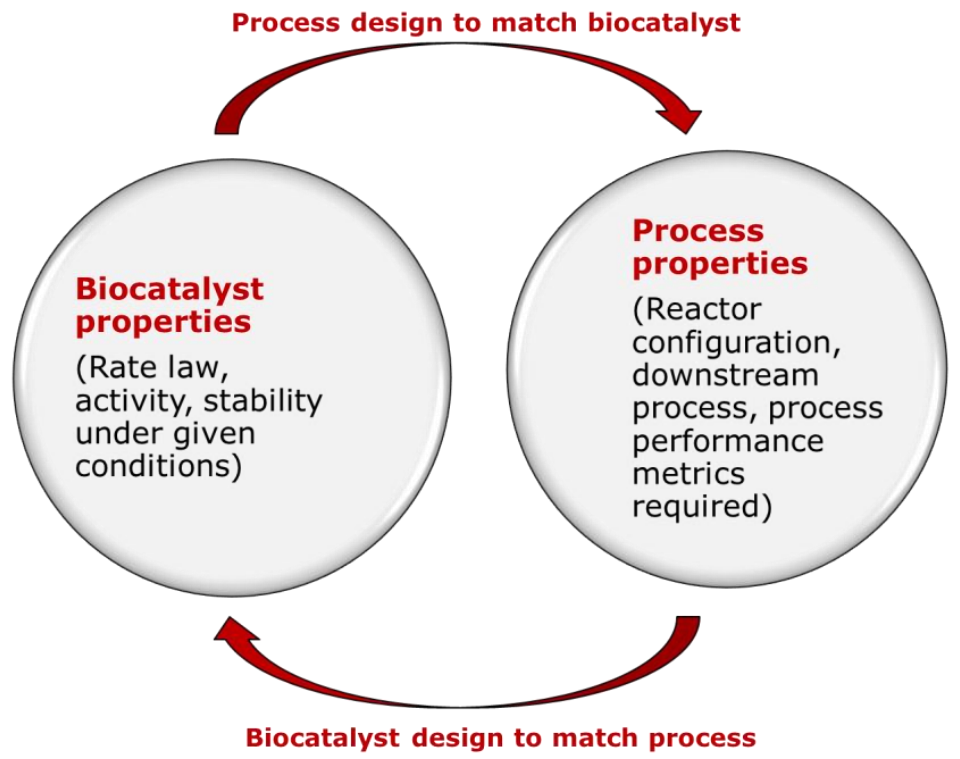

